\title{
As metamorfoses da comédia
}

\section{The comedy metamorphoses}

\author{
Igor de Almeida Silva ${ }^{1}$
}




\section{Resumo}

Este artigo apresenta um estudo da comédia enquanto gênero dramático, observando suas especificidades teóricas, além de discutir alguns elementos e conceitos fundamentais do gênero, tais quais fábula, personagem, espaço, tempo, ação, linguagem, catarse, entre outros, tomando como ponto de partida a Poética de Aristóteles, a fim de poder fornecer pressupostos de análise para seu estudo. Pretende-se tratar da diversidade de abordagens e conceitos acerca da comédia, assim como da variedade de subgêneros na dramaturgia ocidental, evidenciando a importância do papel do leitor-espectador na definição do que constitui uma comédia.

Palavras-chave: Comédia; riso; comicidade; poética; dramaturgia

\section{Abstract}

This article presents a study of comedy as a dramatic genre, observing its theoretical specificities, and discusses some fundamental elements and concepts of the genre, such as fable, character, space, time, action, language, catharsis, among others, taking as point of departure the Poetics of Aristotle, in order to be able to provide tools of analysis for his study. It is intended to deal with the diversity of approaches and concepts about comedy, as well as the variety of subgenres in Brazilian and world dramaturgy, highlighting the importance of the role of the reader-spectator in defining what constitutes a comedy.

Keywords: Comedy; laugh; comic; poetic; dramaturgy

ISSN: 1414.5731

E-ISSN: 2358.6958

1 Prof. Dr. Universidade Federal de Pernambuco (UFPE) - Depto de Teoria da Arte e Expressão Artística. igordealmeida.silva@gmail.com 
Se a rica tradição da comédia permite-nos seguir seu desenvolvimento no mundo ocidental, de suas origens à contemporaneidade, por outro lado, seu caráter multifacetado torna difícil uma definição precisa e unívoca deste termo. Tal dificuldade deve-se, sobretudo, ao descrédito conferido à comédia pelos eruditos ao longo dos séculos, especialmente na Antiguidade clássica e nos séculos XVI e XVII. Julgam-na menor em relação à tragédia e, posteriormente, ao drama, não recebendo por isso a mesma atenção que estes gêneros. Além disso, suas constantes metamorfoses e sua diversidade de interpretações ajudaram a torná-la ainda mais flutuante e imprecisa em sua natureza. Prova disso são as ramificações e transformações pelas quais sofreu: comédia antiga e comédia nova, comédia alta e comédia baixa, comédia burlesca, comédia-balé, comédia de caráter, comédia de costumes, comédia de intriga, comédia de situação, comédia de capa e espada, comédia heroica, comédia lacrimosa, etc.

Dessa forma, podemos abordá-la tanto em contraposição à tragédia, "identificando um tipo de peça teatral em que os personagens pertencem a uma humanidade menor e cujas peripécias conduzem a trama a um desfecho feliz" (Brandão, 2006, p. 85-86) - a Poética, de Aristóteles, seria a matriz teórica dessa concepção da comédia -; como diferençá-la em oposição à farsa, "que seria uma irmã menor mais irreverente e ousada, menos comportada e dotada de ambições literárias mais estreitas" (Brandão, 2006, p. 86). Também a comédia, segundo alguns autores, sobretudo os mais recentes, não se confunde mais com a noção de cômico. Para muitos, este termo teria desdobramentos muito mais filosóficos do que literários ou teatrais, onde nem o cômico se restringiria apenas ao teatro feito para rir, nem a comédia se limitaria à comicidade e ao riso. Esta é inclusive uma das ressalvas ao clássico livro de Henri Bergson sobre o tema, O riso: ensaio sobre a significação da comicidade (2004), no que concerne à sua influência nos estudos da comédia. Neste livro, ela é o principal substrato para a edificação de sua teoria do riso, porém não é de fato seu objeto de estudo. Como diz Eric Bentley (1991, p. 197-198): "Seu assunto principal não é a comédia, mas um subproduto comum da comédia. Sua primeira função é a análise da natureza humana, não a avaliação de obras de arte".

Michel Corvin (1994) afirma que a comédia se distingue por ser, ao mesmo tempo, um gênero e um conceito. Enquanto gênero, ela se define a partir de características e procedimentos literários e estético-sociais extremamente precisos que, por sua vez, são apenas determinantes em seu estudo, se analisados coletivamente. É da análise de suas relações que surge seu significado: "a especificidade da comédia reside em um conjunto coerente de elementos abstratos, uma convergência de traços nos quais a presença simultânea, ao menos da maioria entre eles, permite dizer que se trata de comédia" (Corvin, 1994, p. XI). ${ }^{2}$ Como conceito, neste caso, a comédia abrange o cômico e, consequentemente, todas as obras saídas do teatro feito para rir, indo da farsa ao vaudevile, do teatro de feira ao teatro de boulevard e ao besteirol carioca. Para o reconhecimento da comédia enquanto gênero literário, Corvin (1994, p. XI) diz:

O signo global de reconhecimento da comédia, [...] é que ela procura agradar pelo

\footnotetext{
2 "La spécificité de la comédie réside en un faisceau, une convergence de traits dont la présence simultanée, au moins de la plupart d'entre eux, permet de dire qu'il s'agit de comédie ». [Todas as traduções do francês são de nossa autoria].
} 
espetáculo de uma desmedida, de um excesso qualquer (na situação, no caráter e na conduta dos personagens, no desenvolvimento da intriga, na linguagem) diante dos quais o espectador toma suas distâncias e se sente reafirmado em sua inteligência e na solidez racional de seu julgamento. $\mathrm{O}$ que não provoca necessariamente o riso: o cômico não é condição nem necessária nem suficiente deste tipo de comédia, assim como ela não procura de maneira nenhuma excluí-lo. ${ }^{3}$

Contrariamente a Corvin, posicionam-se diversos pensadores e pesquisadores, de Aristóteles à contemporaneidade, para os quais o riso é a finalidade a qual a comédia se destina, como nos diz Pierre-Aimé Touchard (1978, p. 35): “O riso, [...] e, mais profundamente ainda, o sentimento de libertação, de ruptura total de que ele é indício, surgem como a própria finalidade da comédia". Se para Touchard, o mundo pode ser visto pelo homem que pensa, como comédia, para aquele que sente, lhe vai bem a tragédia. Mas este aspecto intelectual, característico da comédia, não necessariamente produz o riso. A atmosfera cômica só nasce a partir do momento em que o indivíduo não se sente mais no jogo encenante; entretanto, ela apenas torna-se verdadeiramente dramática, ou seja, digna de ser levada à cena, quando atinge um distanciamento crítico, intelectualizado como ele mesmo diz, que se dá a ver através do riso:

A partir do momento em que o personagem no palco não mais representa a mim mesmo no instante em que vivo, assim que se converte no outro (e esse outro que sou eu no passado e no futuro), desenvolve-se a comédia. [...] trata-se sempre de um outro que não sou eu ou de um eu que rejeito. No caso, o único compromisso possível é aquele que supõe a vontade de ruptura. Desse caráter fundamental da atmosfera cômica decorrem os demais. (Touchard, 1978, p. 32)

Faz-se necessário, porém, que na comédia também haja certo tipo de identificação: o espectador deve ver nas personagens cômicas, figuras de carne e osso para nelas espelhar-se, pois só assim "em presença do homem real, que o personagem de teatro substitui, tanto mais ao explodir no teatro, ganhará em força cômica: tanto mais será uma libertação" (Touchard, 1978, p. 35). [rifo nosso].

A atmosfera cômica implica em uma necessidade de ruptura com o que se mostra no palco, mas esta ruptura não é total, tão completa como desejaria Touchard. Ele mesmo reconhece que Bergson observou que sempre se deve reconhecer o homem no personagem cômico: "Se não houvesse mais do que um autômato, que de modo algum lembrasse o homem, o riso não acharia seu alimento do mesmo modo como não o encontra quando há apenas um jogo de palavras. Um motor não faz rir. Por estar dissociada da sensibilidade, a atitude do espectador de comédia não é totalmente intelectual" (Touchard, 1978, p. 36). Para Touchard, a recepção da tragédia diferencia-se da comédia porque, diante da primeira, o espectador entrega-se inteiramente, recebendo um mundo revelado de sentimentos e paixões que na vida real dificilmente se permitiria; já em relação à segunda, o espectador segue seu caminho em terreno conhecido. Enfim, o personagem cômico torna-se algo do próprio indivíduo (não é ele, como seria na tragédia), assegurando-lhe então domínio sobre ela

\footnotetext{
${ }^{3}$ « Le signe global de reconnaissance de la comédie [...] est qu'elle cherche à plaire par le spectacle d'une démesure, d'un excès quelconques (dans la situation, le caractère et la conduite des personnages, le déroulement de l'intrigue, le langage) en face desquels le spectateur prend ses distances et se sent raffermi dans son intelligence et la solidité rationnelle de son jugement. Ce qui ne provoque pas nécessairement le rire: le comique n'est la condition ni nécessaire ni suffisante de cette comédie-là, bien qu'elle ne cherche nullement à l'exclure ».
} 
e, ao mesmo tempo, propiciando-lhe um prazer específico, por despertar-lhe uma reflexão, um sentimento profundo sobre a própria natureza humana.

Que os personagens cômicos sejam de baixa ou alta condição social, ou ética, ou que o desfecho de uma comédia seja o de um final feliz, nada disso é estritamente fundamental no trabalho do comediógrafo, pois o seu principal objetivo é conquistar a participação do espectador, conduzindo-o em um "jogo cujo objetivo é o de deixar cair o maior número possível de máscaras" (Mendes, 2008, p. 84). O que Cleise Mendes sugere é que o que vai importar nisso tudo é a ação cômica que a tudo desestabiliza, exatamente porque implica numa valorização daquilo tido como "baixo". Porém, esse destaque ao que se encontra "embaixo" não incide exatamente na representação do "objeto imitado", mas num olhar que converte para baixo o ângulo de visão do comediógrafo. Trata-se muito mais de um modo de ação do que de imitação:

[...] a ação cômica não prescinde da trajetória pelo baixo, pela materialidade, pelo corpo. Mas 'o baixo não é tanto aquilo que se representa (vícios, desvios, falhas, referência a 'partes inomináveis' etc.) quanto o ângulo de onde parte a visão. O olhar cômico desconfia das "altitudes" e produz um gesto de rebaixamento no sentido de que puxa para baixo tudo que caia no seu ângulo de visão. (Mendes, 2008, p. 85)

A comicidade poderá então ser compreendida não como uma forma de representação do que é ou está embaixo, mas "como uma força que 'puxa para baixo', que instala a crise, que divide, faz rachar, estalar a superfície de toda imagem solene, fechada em sua gravidade, polida, monolítica" (Mendes, 2008, p. 86). Essa força se manifesta ao colocar "em movimento, em circulação, novas e novas formas dramáticas, sempre cambiáveis, sempre em mutação segundo o desgaste provocado pelo atrito com outras forças, em cada tempo e espaço" (Mendes, 2008, p. 86). Daí que o prazer em ver desabar "as coisas elevadas"; "seu rebaixamento" (Bakhtin, 1987) provém exatamente desta força cômica que "rebaixa" tudo o que teima em se manter no alto.

Posição a dialogar com Touchard e Cleise Mendes é a de Ivo Bender (1996) que, retomando a Poética, de Aristóteles, no estudo da comédia, a partir de Richard Janko (1984), sintetiza as principais características que constituem a catarse cômica: ao contrário da tragédia, que utiliza a compaixão e o temor para purgar as emoções do espectador, a catarse cômica expia suas paixões "pelo alívio de tensões previamente suscitadas que, esvaziando-se, dão lugar ao riso" (Bender, 1996, p. 52).

Dessa maneira, compreende-se porque a apreensão da comédia torna-se tão laboriosa. Quase todos os autores que se debruçaram sobre seu estudo almejaram a edificação de um conceito unívoco, talvez de fato só vislumbrado na obra de Molière (1622-1673), onde a alta e a baixa comédia se mesclavam perfeitamente. Porém, tal crise da comédia deve-se, sobretudo, a uma profunda esclerose dos gêneros transmitida pelo classicismo. Em detrimento da ambição dos eruditos do século XVII de separar a comédia de suas origens populares e de "elevá-la" ao status de gênero literário, a comédia e, também o teatro como um todo, foi pouco a pouco enfraquecendo-se e descaracterizando-se enquanto arte específica. Assim, a comédia (e também o teatro) ligou-se a uma tradição que lhe era artificial, de concepção estritamente literária, permanecendo mal interpretada por um longo período. 
A comédia, que sempre foi um gênero marginal, de fato, só adquiriu autonomia e respeitabilidade a partir do século XX com o advento do encenador que a redimensionou e a recolocou no seu lugar de direito: o palco. Além disso, ela passou a receber uma considerável atenção por parte de teóricos e pesquisadores que progressivamente vêm lhe dedicando numerosos estudos. Mas, diante das transformações da sociedade e dos próprios rumos do teatro, a comédia metamorfoseou-se e ramificou-se ao máximo. Sobretudo, a partir da dissolução dos gêneros, já ensaiada por Denis Diderot (1713-1784) no século XVIII com sua comédie sérieuse ${ }^{4}$ (subgênero do que se convencionou chamar de drama burguês - genre sérieux - e que seria a matriz do drama moderno), adquirindo forma plena em dramaturgos modernos do porte de Anton Tchekhov (1860-1904), Luigi Pirandello (1867-1936), Bernard Shaw (1856-1950) e Samuel Beckett (1906-1989), que não abriam mão do humor, da ironia e do senso de ridículo, ou seja, da comicidade de um modo geral, mesmo que em suas obras não deixassem de mostrar o lado trágico da condição humana.

No século XX, na França, presenciou-se o rejuvenescimento da comédia burguesa sob a pena de Marcel Pagnol (1895-1974), Jean Giraudoux (1882-1944) e Jean Anouilh (1910-1987) e a força do teatro de boulevard que ainda ressoa na contemporaneidade. Sem falar ainda nos efeitos transgressores que o teatro do absurdo provocaria na dramaturgia aristotélica, subvertendo a lógica e a linguagem, além de redescobrir a farsa, o teatro de marionete e o jogo clownesco, tendo como principais representantes Arthur Adamov (1908-1970), Eugène Ionesco (1909-1994) e Samuel Beckett que, em seu teatro, foi para além das fronteiras do gênero.

No Brasil, nossa tradição no gênero cômico, iniciada por Martins Pena (18151848) no século XIX, com o Romantismo, foi continuada por Joaquim Manuel de Macedo (1820-1882) e por França Júnior (1838-1890). Mas há de se mencionar a presença de outros dramaturgos que, envolvidos com o Realismo francês, no Teatro Ginásio Dramático, estiveram a propor uma comédia que tivesse fins moralizadores e que pudesse elevar a qualidade artística, firmando o teatro nacional: eram dramaturgos como José de Alencar (1829-1877) e Machado de Assis (1839-1908), cada um deles com ideário e perspectiva estética próprios. No entanto, um dramaturgo não alinhado a nenhuma escola e que seria precursor até mesmo do teatro surrealista, Qorpo Santo (1829-1883) - embora nascido e vivendo em pleno século XIX -, só teve sua obra reconhecida nos anos 1960 do século XX, devido à desrazão que se lhe acometera, não tendo o crédito de seus contemporâneos. Artur Azevedo (18551908) inaugurou um gênero especial no Brasil, do final dos Oitocentos: a paródia da opereta, que fez enorme sucesso e o autor acabou enveredando para a revista e para a burleta, escrevendo uma obra-prima: A capital federal. No que concerne à comédia de costumes, no decorrer do século $\mathrm{XX}$, vários autores continuaram a produzi-la, especialmente nas três primeiras décadas da República Velha, através da "Geração Trianon", da qual faziam parte Gastão Tojeiro (1888-1965) e Armando Gonzaga (1889-1954), além de Oduvaldo Vianna (1892-1972). Ressalta-se que a comédia, como gênero, continuava a atrair autores e público. E a revista continuou seus

${ }^{4}$ « [...] 0 homem [...] não vive nem no trágico nem no cômico, mas em situações intermediárias que podemos chamar 'sérias' » (Abirached, 2000:193). "[...] l'homme [...] ne vit ni dans le tragique ni dans le comique, mais dans des situations intermédiaires qu'on peut appeller 'sérieuses'”. Cf. também Diderot (2005). 
tempos de glória até os anos 1950. Diversos dramaturgos exercitaram-se no gênero, variando da comédia de costumes à comédia séria e à farsa. Exemplos que podemos nomear são os de Silveira Sampaio (1914-1964) e de Millôr Fernandes (1923-2012), passando pelo teatro dos anos 1960, onde Oduvaldo Vianna Filho (1936-1974) e Ferreira Gullar (1930-2016) nos legaram uma sátira política de grande contundência, Se correr o bicho pega, se ficar o bicho come; mas não faltaram os temas da atualidade: da psicanálise à decadência da aristocracia de quatrocentões paulistas por intermédio, por exemplo, de um Jorge Andrade (1922-1984), em Os ossos do barão. E Nelson Rodrigues (1912-1980) enveredou por "farsas irresponsáveis" como Dorotéia e Viúva, porém honesta, nas quais a família, a imprensa, o teatro e o próprio público são "desconstruídos" pela sua pena. Também havia experimentado a farsa Oswald de Andrade (1890-1954) em seu O rei da vela. Ariano Suassuna (1927-2014) trouxe para o palco brasileiro a força da literatura popular mesclada com a erudita e produziu o Auto da Compadecida, desmascarando a tartufice nacional pelos "amarelinhos" João Grilo e Chicó: religiosidade em tempos de comicidade em uma época em que "gato descomia dinheiro". Osman Lins (1924-1978) fez sucesso com sua Lisbela e o prisioneiro. Joaquim Cardozo (1897-1978), com seu Coronel de Macambira e Luiz Marinho (1926-2002), com: Um sábado em 30. Os temas sempre se atualizando e as novas formas dando asas à imaginação dos comediógrafos. O sexo sempre em cena, com todas as infidelidades conjugais, possíveis e inimagináveis, como a retomar-se o vaudevile que talvez já se tivesse esgarçado na memória enquanto gênero cômico. E a política nacional servindo de achincalhe para muitos dramaturgos: rindo e castigando costumes, mazelas. Tarimbados teatrólogos souberam fazer rir, e o público riu a bandeiras desfraldadas. Finalmente, chegamos à explosão do teatro de besteirol, a partir dos anos 1980, estendendo-se à atualidade, representado por Miguel Falabella (1956-), Vicente Pereira (1950-1993) e Mauro Rasi (1949-2003), onde o cotidiano de determinada parcela da classe média carioca, foi "virado de ponta cabeça", fenômeno que repercutiu em Salvador com $A$ bofetada e no Recife em espetáculos da Trupe do Barulho, especialmente com Cinderela, a história que sua mãe não contou; tudo de forma volátil, como convinha aos "tempos pós-modernos" que se redesenhavam.

Diante da exposição dos problemas que constituem a tentativa de uma definição da comédia, chegamos a pensar, como Eric Bentley, que vê com profundo ceticismo qualquer tipo de normatização, se não "deveríamos ficar satisfeitos em ler as comédias sem saber exatamente o que é a comédia" (1991, p. 234), pois como nos diz Henry James, citado por Bentley: "só uma comédia, e nada mais que uma comédia, é uma comédia" (1991, p. 197). Bentley acrescenta com acidez: "Termos críticos nunca podem significar mais do que aproximações e conveniências. Quando tornam-se campos de batalha, quando alguém deseja saber qual das variedades significa a coisa real, escapamos do discurso racional para a superstição" (1991, p. 198).

Entretanto, preferimos retomar nossa disposição de outrora e pensar como Corvin que, depois de refletir sobre a natureza da comédia tanto quanto gênero como conceito, conclui que os mecanismos por ela empreendidos enquanto gênero literário são da mesma natureza das pulsões que nos levam ao riso. A confusão conceitual que a perseguiu desde seu nascimento, opondo a comédia literária (alta comédia) à comédia popular (farsa, teatro de feira, soties, etc.), mostra-se benéfica para ambas, 
pois permite o acesso tanto à análise literária e dramatúrgica de uma e de outra, quanto a uma reflexão de ordem filosófica, incluindo os fundamentos do cômico e do riso, assim como questões morais, sociais e estéticas, pertinentes à comédia.

Mais do que a tragédia e o drama, a comédia realiza-se em plenitude sobre um palco à mercê do olhar do público. É o riso do espectador que determina sua especificidade cênica. Interação que se dá por meio do riso, mais vibrante e perceptível do que a comoção ou o choro da plateia diante de uma tragédia ou drama, capaz de interferir na continuidade da cena e no desempenho do ator. O riso é a resposta espontânea do público, de como ele está se relacionando com o espetáculo, se este lhe agrada ou não, se corresponde às suas expectativas de boa diversão ou se compreende o humor e a ironia da representação. Torna-o, portanto, mais vulnerável aos seus humores do que os outros gêneros, norteando, inclusive, os rumos da cena no mesmo instante em que ela se realiza.

Raciocinando assim, pretendemos abordar a comédia, no decorrer destas páginas, a partir dos elementos que a diferenciem dos demais gêneros dramáticos (tragédia e drama); ver qual a especificidade da fábula, dos personagens, do espaço, do tempo e da linguagem na comédia. Discuti-la, enquanto gênero dramático, sem perder de vista sua natureza cênica, assim como seus aspectos risíveis que garantem sua comunicabilidade com o leitor-espectador.

\section{Fábula e comédia}

O primeiro estudo referente à comédia de que temos notícia é $A$ poética, de Aristóteles. Apesar das escassas referências que o autor faz ao gênero cômico, citando-o em oposição à tragédia, de maneira negativa, definiram-se algumas das características que, para o bem e para o mal, ajudaram a solidificar a presença da comédia na história das artes e do pensamento. A comédia, assim como os demais gêneros e linguagens artísticas citadas pelo autor (a epopeia, a dança, a música, a pintura), não representa o centro das atenções do filósofo. Sua teoria centra-se na questão do gênero trágico: quais são as regras necessárias para o reconhecimento e a elaboração de uma tragédia; o que a constitui e o que a distingue das outras artes e gêneros literários. A comédia, portanto, ocupa uma posição secundária na obra, sendo citada apenas nas primeiras páginas do livro. Aristóteles promete falar sobre a comédia no decorrer do estudo, mas tal promessa não chega a ser cumprida. Presume-se que a comédia faria parte de um segundo livro da Poética, que infelizmente não chegou até nós.

O autor refere-se à comédia como imitação de homens inferiores. Entretanto, esta imitação não abrange toda espécie de vício, mas apenas o que é ridículo. Portanto, o ridículo seria um defeito, torpeza anódina e inocente. As alusões da comédia, na Poética, resumem-se a poucas palavras sobre a origem do teatro cômico, sobre a imitação na comédia de homens inferiores que, por isso, seriam risíveis em sua falha cômica. Como alternativa a sua escassez de informações sobre a comédia, pode-se recorrer ao Tractatus coislinianus (Janko, 1984), epítome de um presumível segundo livro da Poética, que teria versado sobre o gênero, sendo uma espécie de contrafação da tragédia, seguindo muito de perto o estudo primeiro de Aristóteles. 
$\mathrm{Na}$ justaposição dos textos referidos, encontram-se elementos comuns aos dois gêneros dramáticos. São exatamente seis as partes qualitativas comuns a ambas: 0 mito ou a trama dos fatos (também chamados de fábula ou enredo), o personagem ou o caráter, o pensamento ou as ideias, a dicção ou a elocução e o espetáculo e a música ou melopeia. O primeiro e mais importante elemento, segundo Aristóteles (384-322 a.C.), é a fábula ou a trama dos fatos. Para o filósofo, a trama dos fatos é a organização do todo que, consequentemente, constitui a peça e que, com as ações, compõem o elemento mais importante da tragédia. Sobre o assunto, assim ele se refere ao tratar da tragédia:

[...] o elemento mais importante é a trama dos factos, pois a tragédia não é a imitação de homens, mas de acções e de vida [...] e a própria finalidade da vida é uma ação, não uma qualidade. Ora os homens possuem tal ou tal qualidade, conformemente ao carácter, mas são bem ou mal-aventurados pelas acções que praticam. Daqui se segue que, na tragédia, não agem as personagens para imitar caracteres, mas assumem caracteres para efectuar certas acções; por isso, as acções e o mito constituem a finalidade da tragédia, e a finalidade é de tudo o que mais importa. (Aristóteles, 1990, p. 111)

A fábula ou a trama dos fatos associada à ação apresenta-se como um dos elementos fundamentais da narrativa dramática. Além disso, será a qualidade das ações que determinará a diferença essencial entre a tragédia e a comédia, de acordo com o filósofo. Ao contrário da tragédia, cuja ação possui um caráter elevado e cujo herói se posiciona acima dos homens devido à sua virtude, renome ou posição social, a comédia, por sua vez, apresenta uma ação absurda, desprovida de qualquer sinal de grandeza. A oposição homem-ordem presente na tragédia, aqui, está ausente, levando a um apequenamento do herói como consequência de suas ações que revelam seus vícios e, por isso mesmo, seu ridículo: "A ordem ou valores que envolvem esse herói serão aqueles encontráveis no cotidiano doméstico, na estrutura social em suas diferentes manifestações ou nas relações interpessoais" (Bender, 1996, p. 22). No Tractatus, o filósofo repete o que dissera sobre a importância da trama dos fatos, mas para a comédia acrescenta o papel do discurso como deflagrador do riso que, segundo Aristóteles, é a finalidade da comédia.

O que isso pode dizer especificamente sobre a comédia? Será que este ponto de vista mais aplicado à tragédia também pode ser válido para a comédia? Sua valorização do conteúdo em detrimento da forma é suficiente para a determinação da comédia em relação aos outros gêneros literários e, sobretudo, aos dramáticos? A especificidade da comédia pode ser apreendida apenas por uma questão de conteúdo ou de sequência de situações? Há uma situação própria à comédia?

Para Pierre-Aimé Touchard (1978), a atmosfera trágica e a atmosfera cômica são definidas a partir da perspectiva do espectador. Ele seria o elemento determinante, pois uma situação só pode ser considerada trágica para quem a vive e cômica para quem a observa. Portanto, segundo o ensaísta, é a partir do leitor-espectador que a comédia se constitui. Sobre a mesma questão, Michel Corvin (1994, p. 148) diz: 
[...] a comédia não é uma obra homogênea na qual situações, personagens, linguagem e tonalidade do todo se harmonizam, entre eles e com o leitor, como o faz a tragédia, a qual é imprescindível referir-se como contraste; é o leitor-espectador que faz a comédia; é dele que é preciso partir para se chegar à fonte da obra. ${ }^{5}$

Contrariamente se posiciona Charles Mauron (2000), que atribui à intencionalidade do autor a capacidade de definição da comédia. Para Mauron, seria a natureza das reações psicológicas que o dramaturgo incita no leitor-expectador a chave para a apreensão do gênero e que no caso da comédia, essas reações se dariam, sobretudo, por meio do riso:

O riso nasce como uma espécie de reflexo psíquico, de diferença de potencial entre duas representações, o chiste suscita esta diferença e joga com ela. Ele aparece, no plano verbal e adulto, como uma derivação do jogo infantil e não cessa de misturar, como toda atividade lúdica, a repetição de situações angustiantes ainda mal controladas, o gozo de habilidades adquiridas, enfim a aprendizagem de uma liberdade superior (Mauron, 2000, p. 23). ${ }^{6}$

Todavia, mesmo atribuindo ao dramaturgo o poder sobre a determinação do gênero, seu reconhecimento não deixa de passar pela recepção crítica do leitor-espectador, seja ela demonstrada através de um sonoro gargalhar, um discreto sorriso ou seu inverso: um silencioso pranto. Ou seja, nem sempre o autor é responsável pela subjetividade de sua obra; sua recepção pode estar tanto em acordo quanto em desacordo com suas propostas estéticas e ideológicas.

$\mathrm{Na}$ definição de fábula, não existiriam qualidades características, procedimentos que demarcassem os campos do trágico e do cômico. O que importa neste caso é o ponto de vista do leitor-espectador. Corvin acentua que, no caso da comédia, há um ponto de vista privilegiado para este leitor-espectador: ele se reconhece e se permite ser plenamente o que é - leitor-espectador - e, em estado pleno de si mesmo, é considerado um deus: "ele o é pela distância propriamente física que afastando-o do hic et nunc da situação e dos acidentes imediatos, dá-lhe a percepção da totalidade no momento mesmo em que o jogo se desenrola" (Corvin, 1994, p. 149). ${ }^{7}$

Tal onisciência deve-se ao conhecimento prévio das artimanhas e dos meandros da comédia: os apartes, as confidências dos personagens que revelam suas reais intenções, as alusões diversas e procedimentos dramatúrgicos específicos. Frequentemente o espectador em sua plenitude possui o conhecimento total das situações e do destino dos personagens cômicos, que desconhecem o que a fortuna lhes reserva. A situação de comédia vivida pelos personagens é vista por eles mesmos de maneira fragmentária, enquanto o leitor-espectador, no geral, a vê e a sente em sua totalidade. Na tragédia, o leitor-espectador compartilha com os personagens das mesmas surpresas por eles vividas, a cada reviravolta do destino. E, quando a situação se unifica para que os personagens possam se dar conta do que até então desconheciam,

\footnotetext{
${ }^{5}$ « la comédie n'est pas une oeuvre homogène où situations, personnages, langage et tonalité du tout s'harmonisent, entre eux et avec le lecteur, comme le fait la tragédie, à laquelle il faut bien se référer comme repoussoir; c'est le lecteur-spectateur qui fait la comédie; c'est de lui qu'il faut partir pour remonter à l'oeuvre ॥". ${ }^{6}$ « Le rire naît, comme une sorte de réflexe psychique, d'une différence de potenciel entre deux représentations; le trait d'esprit suscite cette différence et en joue. II apparaît, sur le plan verbal et adulte, comme un dérivé du jeu enfantin et ne cesse pas de mêler, comme toute activité ludique, la répétition de situations angoissantes encore mal contrôlées, la jouissance de maîtrises acquises, enfin l'apprentissage d'une liberté supérieure ».

${ }^{7}$ « il l'est par la distance proprement physique qui, l'éloignant du hic et nunc de la situation et de ses accidents immédiats, lui donne la perception de la totalité au moment même où la partie se déroule».
} 
esta já é fato conhecido do leitor-espectador que, no esquema de comédia, está ligeiramente à frente do herói.

\section{O Personagem da Comédia}

O segundo elemento apontado pela Poética é o personagem. Na comédia, ele aparece rebaixado, pois se "o herói trágico é a representação de homens melhores do que a média, o herói cômico retrata homens piores. Essa inferioridade deve ser entendida, porém, como o resultado do herói apresentar falhas ou vícios risíveis" (Bender, 1996, p. 23). Observa-se que ambos os heróis são portadores de falhas. Entretanto, o aniquilamento geralmente encontrado no herói trágico não se faz presente na comédia. A falha cômica levará o protagonista ou à sua felicidade pessoal ou à sua punição e à alegria geral dos que o cercam, além de propiciar o riso: "Da exposição da falha jocosa, passando pelas peripécias até atingir o clímax e a acomodação final, o trajeto a ser percorrido pode mesmo implicar o saneamento do defeito, a resignação a ele ou [...] a submissão do sujeito a castigos que visem a sua correção" (Bender, 1996, p. 24). Seus vícios e defeitos são inofensivos, ridículos e, por isso mesmo, risíveis.

$\mathrm{Na}$ tragédia, o protagonista sempre age sozinho. A liberdade que o faz assumir a responsabilidade por seus atos é acentuada pelo fato de agir solitariamente. Mesmo que se encontrem nas tragédias gregas personagens que acompanham temporariamente os protagonistas, tais personagens existem apenas como um recurso dramatúrgico do autor: "o outro se faz necessário para enfatizar a singularidade do caráter do herói e a radicalidade de seu ato" (Bender, 1996, p. 38). Em contraposição, na comédia, o outro é presença constante, sendo fundamental para o desenvolvimento da ação e do enredo. Dificilmente agindo sozinho, o protagonista conta sempre com o auxílio de criados, escravos, irmãos gêmeos, parentes ou amigos que podem servir tanto como duplos quanto como cúmplices para o cumprimento de suas peripécias e para a realização de seus desejos.

O personagem cômico pode, ainda, apresentar diferenciações que o individualizam do tipo. Por exemplo: um criado (un valet) pode ser covarde ou violento, esperto ou estúpido; o enamorado, tímido ou brutal; o mestre, autoritário ou palerma. Em verdade, ele não se limita ao tipo, nem se restringe também à travessia que leva do individual à caricatura. Ele se situa num movimento mais complexo e dialético onde as fronteiras entre personagem e tipo não são precisas, pendendo ora para um lado, ora para o outro. Na commedia dell'arte, não é em decorrência da máscara do ator que o tipo se dissocia do indivíduo; sem dúvida, ele se apaga junto com os traços do rosto, porém o tipo é anterior ao próprio indivíduo, vindo de uma tradição cultural que coloca em jogo os traços fundadores do personagem, mesmo que ele seja representado com ou sem máscara.

De modo geral, os traços caricaturais que notabilizam o personagem cômico e que também condicionam sua ação lhe são imanentes. Porém, ele foge do "tipo" ao apresentar características individualizantes que independem de uma tradição teatral. Ao mesmo tempo em que o herói carrega um traço caricatural, ele apresenta também outra característica qualquer que o individualiza, ou que o historiciza, distinguindo-o de outros personagens semelhantes ou de uma mesma tradição teatral. Este herói 
escapa do "tipo" e se aproxima do personagem que tem "personalidade", "psique". Daí seu caráter ser paradoxal, pois, frequentemente, o que nele há de caricatural vai contra o que lhe é peculiar, ímpar, histórico, provocando-lhe uma contradição interna e deflagrando sua comicidade: "ele não é o que acredita ser [...] não age como diz agir [...] A contradição entre o ser e o parecer, entre o dizer e o fazer, entre o subjetivo e o objetivo, todas essas digressões estão na base do julgamento que preenche o leitor do sentimento de sua superioridade" (Corvin, 1994, p. 155). ${ }^{8}$

Um exemplo seria o personagem molieresco Alceste do Misantropo, conhecido por sua irritabilidade (traço caricatural), mas ao mesmo tempo particularizado por seu ardoroso estado de paixão por Célimène (traço individualizante). L'atrabilaire amoureux (Alceste), ou melhor, o rabugento enamorado encontra-se impedido na realização de seus desejos amorosos em consequência de seus traços caricaturais (a rabugice) que vão na contracorrente de suas ambições, denunciando sua impossibilidade de se realizar plenamente como personagem (indivíduo) por ainda estar preso aos seus traços caricaturais de tipo, sua função primeira. Um apaixonado que não age, que não exprime seu amor como deveria, que o usa como mais uma justificativa para empreender suas querelas. Ele ama Célimène, mas se mostra incapaz por estar demasiado preso a sua rabugice. Tal irrealização revela seu ridículo e deflagra sua comicidade diante do leitor-espectador.

Entretanto, faz-se necessário evitar certos reducionismos que levam todo personagem ao tipo, a uma simples oposição de forças ou a um binarismo de oposições. Nem se pode chegar ao extremo de uma concepção personalista do personagem, como uma entidade independente, de existência quase extra-teatral. Ele é um personagem, mas em busca de uma personalidade. A ideia é que o personagem cômico é fruto de uma generalização que o projeta para fora do individual; o tipo seria uma intensificação que o desenha no limite do individual. Harpagon não é um tipo por ser avarento, mas por se apresentar como o avarento por excelência. $O$ personagem cômico define-se, portanto, como uma mistura entre o tipo e a personalidade. Ele é simultaneamente ou quase sucessivamente Alceste e o Misantropo, Harpagon e o Avarento, Tartufo e o Impostor. A caricatura e o individual são duas versões de um mesmo personagem. A ação é o personagem ambíguo, pois ele não é nem Alceste nem o Misantropo, mas Alceste, o Misantropo; nem Tartufo nem o Impostor, mas Tartufo, o Impostor. O personagem inclui o tipo e a personalidade em acordo ou em desacordo.

Segundo Henri Gouhier (1952), a simpatia9 que surge entre o espectador e o personagem dissipa-se na comédia na medida em que o personagem cômico se despoja de uma historicidade pessoal, o que permite ao espectador um conhecimento mais profundo de sua personalidade e, consequentemente, o estabelecimento de

\footnotetext{
${ }^{8}$ « il n'est pas ce qu'il croit être [...] il n'agit pas comme il dit qu'il le fait [...] La contradiction entre l'être et le paraître, entre le dire et le faire, entre le subjectif et l'objectif, tous ces écarts sont à la base du jugement qui remplit le lecteur du sentiment de sa supériorité ».

${ }^{9}$ Henri Gouhier usa o termo simpatia em lugar de identificação para designar a relação entre o espectador e o personagem. Partindo da concepção de Pierre-Aimé Touchard sobre a identificação, calcada no reconhecimento do espectador no personagem, como em um processo de espelhamento, em que o primeiro enxerga a si mesmo projetado no segundo, Gouhier afirma que, no lugar da identificação, o que há entre ambos é uma simpatia na qual o espectador não vê o personagem como um reflexo de si mesmo, mas reconhece-o unicamente como semelhante, isto é, "ele [o personagem] é um Eu como eu também sou em mim mesmo. Eu o amo não como se fosse eu mesmo, mas porque ele é um Eu e todo ser, que tenha dignidade, desperta o amor" (Gouhier, 1952, p. 135). « il [o personagem] est un moi comme j'en suis en moi-même. Je l'aime non comme s'il était moi mais parce qu'il est un moi et que tout être ayant la dignité d'un moi appelle l'amour ».
} 
vínculos afetivos. A existência histórica adquire sua tonalidade dramática a partir da consciência de sua finitude, do fim que ameaça a existência e cujo sentido trágico ressoa em profundidade:

O que acontece parece dramático ou trágico a um espírito que fixa o real com o desejo de ir até o fim ou até o fundo de sua historicidade. O cômico requer um outro tratamento: não se trata mais da existência colocada a nu, mas de uma existência submetida a um tratamento que a esvazia de histórias demasiado pessoais. (Gouhier, 1952, p. 138-139) $^{10}$

No momento em que se toma conhecimento da vida que estende aquela essência sob o palco, torna-se impossível negar-lhe uma simpatia ou mesmo uma antipatia. Não se ri do tropeçar de um homem cego, quando os motivos de sua cegueira são colocados em questão pela queda, refletindo sua própria decadência física e espiritual, as condições de sua existência. A historicidade do personagem veta sua comicidade. Não obstante, Henri Gouhier (1952) vislumbra o personagem cômico além das fronteiras do tipo. Ele é um esquema que só se pode desenvolver inserido em histórias, tempos e espaços, cuja historicidade, deve estar em intrínseco diálogo com sua essência:

Daí sua ambiguidade que o situa entre a essência intemporal e a existência histórica: como essência, sobressai-se da existência histórica, mas, aberto sobre a existência histórica, ele não significaria nada se não já fosse, de alguma forma, aquilo que ele se tornará. Ainda que não seja mais uma personalidade, ele é ainda um personagem: um personagem em busca de personalidade. (Gouhier, 1952, p. $157)^{11}$

\section{A comédia e seu espaço}

O espaço na comédia torna-se algo a se proteger ou conquistar, seja fisicamente, seja metaforicamente. Para que possamos identificar o personagem cômico, é necessário que o seu status social médio seja identificado, ou melhor, situado em um ambiente familiar onde os objetos preciosos (pequenos tesouros ou jovens virgens) sejam isolados do mundo, ou seja, do que se encontra no lado de fora, onde os usurpadores (ladrões ou conquistadores) rondam. Fato que explica por que diversas obras clássicas contam a história de agressões vindas do exterior em direção à violação da intimidade familiar. Essas violações dos agressores (realizadas por jovens sedutores, conquistadores e enamorados, por exemplo) confrontam-se com os guardiões naturais, pais de família ou velhos libertinos. Uma vez conquistada a vitória, termina o enclausuramento, no duplo sentido de proteção e prisão. Entretanto, a simplicidade deste esquema dentro/fora ou agressão/defesa não torna monótona a exploração do espaço, pois agregado a este esquema encontram-se diversas nuanças a serem desenvolvidas.

\footnotetext{
${ }^{10}$ « ce qui arrive paraît dramatique ou tragique à un esprit qui fixe le réel avec la volonté d'aller jusqu'au bout ou jusqu'au fond de son historicité. Le comique requiert un autre traitement: il ne s'agit plus de l'existence mise à nu, mais d'une existence soumise à un traitement qui la vide d'histoires trop personnelles ».

${ }^{11}$ « De là son ambiguïté qui le situe entre l'essence intemporelle et l'existence historique: comme l'essence, il est détaché de l'existence historique, mais, ouvert sur l'existence historique, il ne signifirait rien s'il n'était déjà, en quelque manière, ce qu'il deviendra. Quoiqu'il ne soit plus une personalité, il est encore un personnage: un personnage en quête de personnalité ».
} 
No que se refere aos valores metafóricos ligados ao espaço, mesmo que sua materialização seja muito mais expressiva, na alta comédia encontramos o ambiente perfeito para seu desenvolvimento e um vasto horizonte para sua interpretação, pois o espaço é muito mais narrado que construído, portanto, desmaterializado e simbólico. A exploração metafórica do espaço é a chave para a interpretação, por exemplo, de Don Juan, de Molière. O protagonista, sempre impulsionado pela força do Eros, busca ininterruptamente a satisfação de uma nova conquista amorosa. Recusa-se veemente à imobilização, ao enclausuramento e à submissão, a qualquer vontade exterior, sejam os laços do matrimônio, seja a própria transcendência simbolizada por Deus, a quem Don Juan desafia e por quem é, posteriormente, vencido. O sedutor conquista, subjuga; depois, rejeita a mulher para poder retornar ao espaço do desejo, sempre em movimento, à procura de novas satisfações que o aliviem provisoriamente até a descoberta de nova conquista. Constantemente, ele é lançado em mobilidade por si mesmo, ainda que seja fulminado por um raio no final da peça, como castigo por desafiar a Deus. Preservando até o fim seu caráter essencial, podemos dizer que Don Juan é a "força que vai", "ele é o movimento".

Talvez estas declinações metafóricas, onde o espaço reconquista o poder de estruturar a obra, que é próprio à comédia clássica, não sejam suficientes para apreender o papel do espaço em gêneros cômicos sem segundas intenções filosóficas, como a farsa e o vaudevile. Na farsa, o espaço está ligado ao corpo; corpo que, por ser maltratado, constrangido, aparece pelo que de fato é: "um conjunto de músculos e membros que remete o homem à sua origem pré-social, ao animal" (Corvin, 1994, p. 167). ${ }^{12}$ No vaudevile, o espaço é rei absoluto, ele é "o oxigênio de sua respiração artificial e a razão de ser de seus personagens" (Corvin, 1994, p. 168). ${ }^{13}$

O vaudevile apresenta a concepção de encontros inesperados, aproximando vários universos entre si, onde personagens até então desconhecidos enfrentam-se seja pela conquista de um chapéu de palha desaparecido, seja pela perda de um bilhete de banco. Coincidências aparentemente gratuitas, todavia, habilmente criadas pelo autor, dão-se por intermédio de entradas e saídas fulminantes, desregramentos de conduta, perseguições cheias de armadilhas nas quais o personagem se perde, esquecendo o objetivo de sua precipitação. Esgotado, extenuado, arrasado, ele suporta a acumulação de aventuras e reviravoltas que não consegue dominar. Tudo isso concorre para a fabricação do ritmo desenfreado do vaudevile.

O vaudevile funciona em função da oposição entre espaços internos e externos. As constantes entradas e saídas, as surpresas e reviravoltas constituem um contínuo jogo de revelação e ocultamento que é enfatizado pela troca de espaços. A cada novo espaço penetrado ou descoberto, dá-se uma nova surpresa, que ora contribui para o sucesso do personagem, ora precipita-o ainda mais na confusão. Tal dinâmica contribui para espaços e personagens novos no redemoinho que é a intriga do vaudevile, interpenetrando espaços e situações que, a princípio ou logicamente, são inconciliáveis. O espaço no vaudevile fragmenta-se e se multiplica em diversos subespaços que aumentam a complexidade da intriga, enredando o personagem mais e mais em suas armações. Por isso, a mudança de espaços é o meio privilegiado que o

\footnotetext{
12 « un ensemble de muscles et de membres, et qui renvoie l'homme à son origine pré-sociale, à l'animal ».

${ }^{13}$ " l'oxygène de sa respiration artificielle et la raison d'être de ses personages ».
} 
autor de vaudevile inventa para mostrar a capacidade de adaptação do personagem. O público, por sua vez, cúmplice do personagem em suas aventuras, acompanha-o quase da mesma maneira, esforçando-se para adaptar-se a cada nova situação, em um ritmo frenético que mal permite um rápido pestanejar.

\section{O Tempo na Comédia}

A urgência do tempo que a tragédia clássica conhece pode ser reencontrada sob o impulso radical e extremo que o vaudevile representa: "ele é torturado por uma espécie de espasmo no qual os soluços o fazem se precipitar de um lugar e de uma situação a outra"14 (Corvin, 1994, p. 170). A forma de se assegurar a unidade de tempo de uma comédia é impossibilitar sua inserção temporal na consciência do herói, que age sempre tomado pelo sentido de urgência exigido pela ação. No caso específico do vaudevile, o tempo esvai-se rapidamente, em um ritmo frenético que anula ele mesmo, retornando à temporalidade calma e humana da situação de origem. Toda peça que descenda do vaudevile compreende a calmaria de seu início e uma nova tranquilidade ao seu final, separados apenas (na estrutura mesma do gênero) por uma avalanche de perseguições e de quiproquós, que ocupa o tempo da ação.

Como se o tempo tivesse servido apenas para colocar entre parênteses a própria existência do espectador, que vem ao teatro disposto a abandonar momentaneamente a monotonia de sua vida, para, logo depois, a ela retornar com o fim do espetáculo. Apesar dos obstáculos e dos riscos de catástrofe, o herói sempre sai ileso ao final da peça, assim como o próprio espectador. Ele, literalmente, morre de rir; porém, depois do espetáculo, volta para casa sereno e da mesma forma como saiu: pouco disposto a refletir sobre questões de ordem mais existencial.

Por motivos diferentes, o tempo é ausente da mais clássica das comédias, a comédia de tipos. Enquanto que no vaudevile o tempo é tão rápido que se torna imperceptível, na comédia de tipos não há razão para a sua existência. $O$ tipo é feito por sublinhar o que não muda no que aparenta mudar, não há mais inscrição temporal possível, apenas uma confirmação do já apresentado e dito, sendo, portanto, o contrário da evolução. O tipo não progride, repete-se; enquanto a fábula existe em função e ao redor do caráter do personagem. Sem caráter não existe fábula neste "tipo" de comédia - a comédia de tipos.

Na comédia clássica, o tempo existe para o personagem; no entanto, este tempo mostra-se menos evolutivo do que cíclico. O tempo da peça é uma temporalidade em atraso, pois existe para que o personagem atinja um nível de consciência - de reconhecimento - que o leitor-espectador já possui. Portanto, o tempo objetivo da situação em si mesma e o tempo vivido pelo personagem não coincidem; o leitor percebe o primeiro e imagina que se trata do segundo. Esta distância é, talvez, o signo mais claro da especificidade do tempo na comédia.

O personagem está sempre atrasado em relação a si mesmo e os monólogos usados nas comédias servem para ajudá-lo, parcialmente, a tomar consciência do que ele é. Entretanto, quando não há monólogos, o personagem de comédia faz

\footnotetext{
14 « il est tenaillé d'une sorte de spasme dont les hoquets le font bondir d'un lieu et d'une situation à l'autre ».
} 
monólogos diante de seu parceiro, anulando sua relação com o outro personagem. O personagem não se situa mais num presente-futuro ou mesmo relacionado com o passado, para se localizar em um presente atemporal.

A noção do tempo na comédia é relativa. No geral, ela é suspensa em detrimento da ênfase no desenvolvimento do personagem e da intriga. Se ela existe, seu emprego compromete os limites do gênero, ultrapassando-o. Ou seja, quanto mais o tempo é conscientizado e colocado em relevância pela obra, mais escapa ao gênero cômico, ou ao menos, retarda o reconhecimento dos signos que the são próprios, aproximando-se do drama e do romance. O tempo romanesco é melhor armado que no teatro para abordar as relações do personagem dentro de uma temporalidade. E, mesmo se opormos o drama à comédia, nesta última tal preocupação é menos determinante, pois é sobre o personagem que ela concentra suas forças (suas características típicas, seus vícios e obsessões) e sobre quem deve recair a atenção do público. A inscrição do tempo na comédia a faz perder sua liberdade de indiferença, a condição primeira do prazer cômico que o faz entrar no campo do drama.

\section{A Linguagem da Comédia}

A dicção ou a elocução é o quarto elemento apontado na Poética e no Tractatus. Neste item, Aristóteles sugere que a dicção se aproxime do falar cotidiano. E, no caso da ficção cômica onde os personagens imitados são geralmente bufões, fanfarrões, impostores ou pessoas estúpidas, o discurso será caracterizado pelo falar popular e comum. No entanto, a comicidade extraída do modo de falar pode apresentar-se também pelo contraste de um vocabulário elevado em oposição a um modo de falar mais baixo, demarcando, ao mesmo tempo, uma diferença social e cultural. Além disso, podem ser acrescentados o dialeto e o sotaque como elementos de comicidade no discurso.

Segundo Corvin (1994), a linguagem da comédia é apreendida em dois níveis totalmente interpenetrados: tanto como material lexical e estilístico, quanto como instrumento dramático. Recebida como procedimento e como ornamento da obra, a linguagem, neste primeiro nível, produz um efeito cômico resultante de uma diferença com a norma. O uso cômico da linguagem permanece, em seu princípio, um meio de expressão, mas um meio de expressão que se volta contra seu usuário devido à distância que ele provoca entre o que é dito e o que é percebido pelo outro (o outro sendo o parceiro ou o espectador). Tanto para a linguagem quanto para a situação, é o leitor-espectador, em última análise que, desencadeado o mecanismo de desdobramento entre o ouvido e o compreendido, torna risíveis as repetições, quiproquós, pataquès (erro de linguagem grosseiro) e outras invenções verbais.

Porém, o estatuto da linguagem na comédia é relativo, se não levarmos em consideração o papel do leitor-espectador na sua significação. O efeito cômico não significará nada ao leitor-espectador, caso ele não possa estabelecer uma forma de

12 "Gambiarra" é um termo utilizado na iluminação cênica para uma ligação elétrica simples, normalmente uma extensão de fio comprido com um ponto de luz que permite o manuseio com facilidade. Pode significar também: ligação improvisada e artesanal, normalmente por falta de materiais; ou circuito de lâmpadas como solução alternativa para decoração. 
compreensão do que é dito, que é justamente o aproveitamento de seu contexto sociocultural. A linguagem está sempre em função de um julgamento de valor, pois resulta de determinantes sociais e culturais do receptor.

\section{Por uma Catarse Cômica}

No percurso deste estudo sobre a comédia, passamos por diversas concepções acerca da natureza e dos aspectos estruturais desse gênero dramático, tendo como eixo e ponto de partida A poética, de Aristóteles. A partir dos vestígios do pensamento do filósofo grego sobre a comédia, avançamos em direção a perspectivas mais recentes, que pudessem compreender a comédia independentemente de seu caráter de oposição ou desprestígio diante da tragédia, como a tradição clássica francesa cristalizou na cultura ocidental. Mesmo que, ali e aqui, a comédia fosse considerada em contraposição à tragédia.

Percebemos que muitos dos elementos que constituem a tragédia, segundo Aristóteles, também podem ser pensados e remodelados de acordo com a natureza própria do gênero cômico, como pudemos constatar no estudo específico da fábula, dos personagens e da linguagem, por exemplo. Mas outro dado que nos chama a atenção é a noção de catarse aplicada ao gênero cômico.

Segundo certos autores, a comédia, sob a perspectiva do riso, buscaria o efeito contrário ao da catarse trágica. Ao invés de permitir a identificação do receptor com a obra e, dessa forma, purgar suas emoções, apaziguá-las, a comédia cinde os pontos de contato. Ela instala o distanciamento entre estas duas instâncias. Na tragédia, o leitor-espectador solidariza-se com o destino do herói trágico através do temor e da compaixão, como se sentisse em si mesmo sua própria desgraça, ou como se pressentisse a mesma susceptibilidade ao castigo e ao aniquilamento. Ou seja, ele se identifica porque, em verdade, teme e apieda-se por si mesmo. Na comédia, o leitor está distante. Observa criticamente, na medida em que o coração não é mais soberano, e sim a razão. O riso, segundo Bergson, seria o fruto espontâneo desse distanciamento crítico, denunciando o que é ridículo e vicioso, o que é mecânico e ao mesmo tempo desviante de uma pragmática social e da própria vida.

Contrário a essa racionalização do riso, Freud, no seu livro Os chistes e sua relação com o inconsciente ([1905] 1996a) e, mais tarde, no seu artigo "O humor" ([1927] 1996b), atribui ao inconsciente as origens do riso deflagrado pelo chiste e à razão as fontes do humor. Nestes dois estudos, ele já faz alusão ao efeito relaxante inerente ao riso, que vinha como uma resposta do inconsciente às nossas tensões mentais. Ele seria uma descarga do excesso de energia concentrada em uma representação mental, encontrando aí livre curso: "Enquanto o sonho é a expressão da realização de um desejo e de uma evitação do desprazer, que leva a uma regressão para o pensamento em imagens, o chiste é produtor de prazer". (Roudinesco; Plon, 1998, p. 113). A conclusões semelhantes chegou o crítico e teórico Charles Mauron [1964 (2000)] ao analisar o gênero cômico sob o viés da psicanálise, notadamente sendo influenciado pelo próprio Freud. Para Mauron, a comédia, desde as suas origens, seria uma fantasia de triunfo que subverte e compensa (psicanaliticamente falando) o sonho angustiante que a tragédia representa. 
Registra-se no Tractatus coislinianus que a comédia propicia por intermédio do prazer do riso a purgação das emoções. Ou seja, o fim a que se destina a comédia mostra-se semelhante ao da tragédia, variando apenas os meios, se é que podemos fazer uma afirmação tão reducionista. Em lugar de sofrermos uma liberação ou drenagem das emoções através do temor e da compaixão que a tragédia nos provoca, esta se dá por meio do riso. Pressupõe-se então que a catarse cômica, assim como a catarse trágica (Freire, 1982), visa a uma homeopatia da alma, ou seja, a purgação das paixões que, neste caso, se daria por intermédio do riso. Eis a catarse cômica que pressupõe o próprio pensamento do gênero, seu modus operandi. Suas motivações e seus fins. Trata-se de uma interpretação entre tantas outras na variegada e, muitas vezes, dispersa bibliografia sobre a comédia.

Esta foi nossa diretriz no estudo da comédia: abordá-la em suas variações, incluindo tanto seus aspectos dramatúrgicos quanto a sua comicidade, sem a pretensão de esgotá-los. Buscamos apenas iluminar a relevância do tema - comédia, riso, comicidade - que a "ideologia da seriedade" (Neves, 1979) acabou confinando às áreas acadêmicas menos "nobres" do conhecimento científico. Aqui, apenas um procedimento de duvidar: do bom tom, do bom gosto, do objeto de estudo par excellence.

\section{Referências}

ABIRACHED, Robert. Comédie. In: DICTIONNAIRE de théâtre. 2. éd. Paris: Encyclopaedia Universalis; Albin Michel, 2000, p. 188-196.

ARISTÓTELES. Poética. Tradução, prefácio, introdução, comentário e apêndices de Eudoro de Souza. 2. ed. Lisboa: Imprensa Nacional/Casa da Moeda,1990.

BAKHTIN, Mikhail. A cultura popular na Idade Média e no Renascimento: o contexto de François Rabelais. Trad. Yara Frateschi Vieira. São Paulo: Hucitec; Brasília: Ed. da Universidade de Brasília, 1987.

BENDER, Ivo C. Comédia e riso: uma poética do teatro cômico. Porto Alegre: Ed. da Universidade Federal do Rio Grande do Sul; Ed. da Pontifícia Universidade Católica do Rio Grande do Sul, 1996.

BENTLEY, Eric. O dramaturgo como pensador: um estudo da dramaturgia nos tempos modernos. Trad. Ana Zelma Campos. Rio de Janeiro: Civilização Brasileira, 1991.

BERGSON, Henri. O riso: ensaio sobre a significação da comicidade. Trad. Ivone Castilho Benedetti. São Paulo: Martins Fonte, 2004.

BRANDÃO, Tania. Comédia. In: GUINSBURG, J.; FARIA, João Roberto; LIMA, Mariângela Alves de (Orgs.). Dicionário do teatro brasileiro: temas, formas e conceitos. São Paulo: Perspectiva; Sesc São Paulo, 2006, p. 85-87. 
CORVIN, Michel. Lire la comédie. Paris: Dunod, 1994.

FREIRE. António. A catarse em Aristóteles. Braga - Pt: Publicações da Faculdade de Filosofia, 1982.

FREUD, Sigmund. Os chistes e sua relação com o inconsciente. In: Obras psicológicas completas de Sigmund Freud: edição Standard brasileira. Trad. Sob a direção de Jayme Salomão. Rio de Janeiro: Imago, 1996a, v. 8.

. O humor. In: Obras psicológicas completas de Sigmund Freud: edição Standard brasileira. Trad. Sob a direção de Jayme Salomão. Rio de Janeiro: Imago, p. 165-169, 1996b, v. 21.

GOUHIER, Henri. Le théâtre et l'existence. Paris: Aubier, 1952.

JANKO, Richard. Aristotle on comedy; towards a reconstruction of Poetics II. Los Angeles: University of California Press, 1984.

MAURON, Charles. Psychocritique du genre comique. Aristophane, Plaute, Térence, Molière. 4. éd. Paris: José Corti, 2000.

MENDES, Cleise Furtado. A gargalhada de Ulisses: a catarse cômica. São Paulo: Perspectiva, 2008.

NEVES, Luiz Felipe Baêta. O paradoxo do coringa e o jogo do poder \& saber. Rio de Janeiro: Achiamé, 1979.

ROUDINESCO, Elisabeth; PLON, Michel. Dicionário de psicanálise. Trad. Vera Ribeiro; Lucy Magalhães. Supervisão da edição brasileira Marco Antonio Coutinho Jorge. Rio de Janeiro: Jorge Zahar, 1998.

TOUCHARD, Pierre-Aimé. Dionísio: apologia do teatro; seguido de O amador de teatro ou A regra do jogo. Trad. Maria Helena Ribeiro da Cunha; Maria Cecília de Morais Pinto. São Paulo: Cultrix; Ed. Universidade de São Paulo, 1978.

Recebido em: 12/10/2017

Aprovado em: 09/01/2018 